Apidologie, 1981, 12 (2), 133-136.

\title{
OXYTETRACYCLINE RESIDUES IN HONEY FOLLOWING THREE DIFFERENT METHODS OF ADMINISTERING THE ANTIBIOTIC
}

\author{
Thor LEHNERT and H. SHIMANUKI \\ Bioenvironmental Bee Laboratory, Agricultural Research \\ Science and Education Administration, U.S.D.A., Beltsville, Maryland 20705
}

\begin{abstract}
SUMMARY
A slight residue of oxytetracycline (OTC) not greater than $0.5 \mathrm{ppm}$ was found in surplus honey in 1 of 3 colonies of Apis mellifera L (1) treated with antibiotic extender patties containing $400 \mathrm{mg}$ OTC. Residues of OTC not exceeding 1.1 and $3.5 \mathrm{ppm}$ were detected in surplus honey from 2 of 3 colonies fed antibiotics in powdered sugar. No residues of OTC were found in surplus honey from 6 colonies fed either antibiotic in sugar syrup or extender patties containing $200 \mathrm{mg}$ OTC.
\end{abstract}

\section{INTRODUCTION}

Care must be taken by apiculturists when feeding honey bees antibiotics for disease prevention to avoid contaminating surplus honey. This can be avoided by the termination of oxytetracycline (OTC) feeding in powdered sugar or sugar syrup at least 4 weeks before the major surplus honey flow.

Extender patties with OTC have been shown to be effective in controlling American foulbrood (WILson et al., 1971) and European foulbrood diseases (LEHNERT and SHIMANUKI, 1980). WILSON (1974) also determined that surplus honey was not contaminated with OTC even when extender patties were left on colonies continuously from spring to fall. Since the formulation of OTC we used in the extender patty for prevention of European foulbrood was different from that used in Wilson's formulation

(1) Hymenoptera, Apidae. 
for prevention of American foulbrood, we fed our extender patties to colonies in tests to analyze OTC residues in surplus honey. In addition, we also analyzed honey samples from colonies fed OTC in powdered sugar and sugar syrup, which are the approved methods for feeding OTC for disease prevention.

\section{MATERIALS AND METHODS}

Colonies were started with $1.36 \mathrm{~kg}$ of bees and a queen 2 months before this test was initiated. Neither the bees nor the equipment had a history of prior drug treatment. Fifteen colonies were used in the test : 3 colonies received $200 \mathrm{gm}$ extender patties containing $200 \mathrm{mg}$ OTC; 3 colonies were fed extender patties containing $400 \mathrm{mg}$ OTC; 3 colonies were dusted $3 \mathrm{X}$ with $28 \mathrm{~g}$ powdered sugar containing $200 \mathrm{mg}$ OTC at 1 week intervals; 3 colonies were fed 2.5 liters of $50 \%$ sugar syrup containing $200 \mathrm{mg}$ OTC; and 3 colonies were unfed controls. Extender patties were made with $133 \mathrm{~g}$ sugar, $67 \mathrm{~g}$ $\overline{\text { CriscoR }^{R} \text { (3) }}$ and TASFPR (3) (5.5\% OTC) (Chas. Pfizer and Co., Inc., New York, NY 10017).

All treatments commenced on May 10. Oxytetracycline in sugar syrup was fed in 0.5 liter jars with an entrance feeder. Jars were replenished until the 2.5 liters of $50 \%$ syrup and OTC was exhausted on May 23. Colonies receiving powdered sugar and OTC were dusted on the ends of the top bars of brood combs to avoid direct contact with brood. Dust treatments were applied on May 10, 17 and 24. Extender patties were placed in the center of the top bars of the brood chamber.

On June 18-20, after the major nectar flow, honey was harvested from the honey super. Queen excluders were used to restrict the queen from laying eggs in combs of the honey super. Patties were still present when honey samples were taken from colonies. A comb with capped honey was removed from the center of each honey super and ca. $250 \mathrm{~g}$ of honey was collected from each comb. The honey was strained into clean jars through cheesecloth to remove wax particles and other debris. The honey samples were then shipped to Donald W. Clarke of Pfizer, Inc., for OTC residue determinations. Details of the Pfizer technique for OTC bioassays are described by WILsON (1974).

\section{RESULTS AND DISCUSSION}

Results of the OTC determinations appear in Table 1 . The results reflect a positive reading of $0.52 \mathrm{ppm}$ in the control honey sample. Since the bioassay is not specific for OTC, it was not surprising that the unheated honey from the control colony exhibited some anti-bacterial activity, because unheated honey contains inhibine (WHITE et al., 1963), which could have inhibited the test organism and yielded a false positive test.

Honey from the 3 colonies treated with extender patties containing $200 \mathrm{mg}$ OTC were free of antibiotic residues. Honey from 1 of 3 colonies that received extender patties containing $400 \mathrm{mg}$ OTC showed a slight OTC residue, but not greater than $0.50 \mathrm{ppm}$. This does not agree with WILson's (1974) results, in which no OTC residue was found in the surplus honey. In 2 of 3 colonies fed OTC in powdered sugar, residue levels were 1.1 and $3.5 \mathrm{ppm}$ in the honey, but honey from the other colony contained no residue, which indicates an uneven distribution of OTC in the

(3) Mention of commercial product in this paper does not constitue an endorsement of this product by the U.S.D.A. 
TABL. 1. - Antibiotic residue in surplus honey stored by honey bees 4 weeks after oxytetracycline (OTC) feeding.

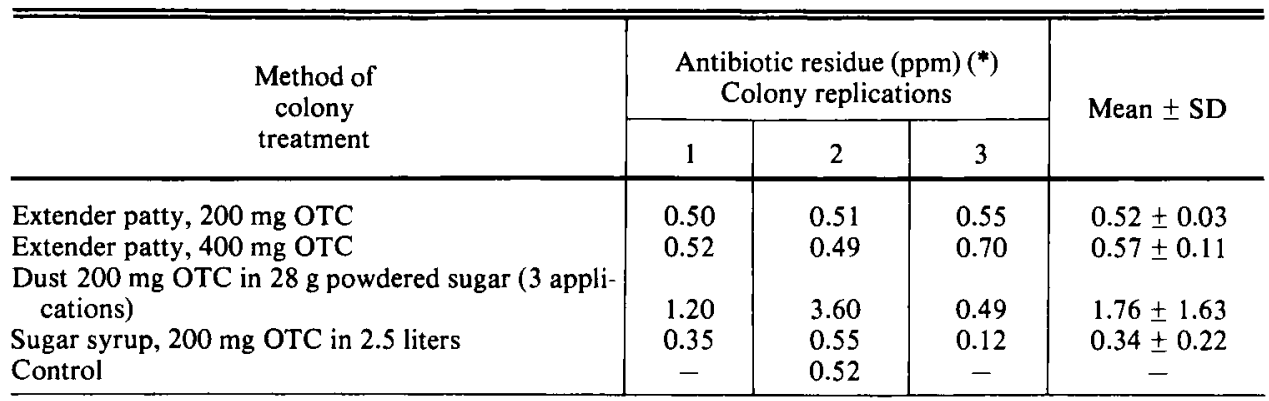

(*) Values of 0.12 to 0.55 are due to inhibine content of honey rather than oxytetracycline residue. D. W. CLARKE, Pfizer, Inc. (1980, personal communication).

honey (WILson, 1974). Honey from colonies fed OTC in $50 \%$ syrup was free of detectable residue. This was expected because Gilliam and ARgauer (1975) showed that OTC breaks down rapidly when fed in sugar syrup.

Our tests indicated that antibiotic extender patties containing $400 \mathrm{mg}$ OTC and powdered sugar containing $200 \mathrm{mg}$ OTC fed to colonies during the honey flow could result in OTC contamination of the surplus honey. All antibiotic feeding should be terminated at least 4 weeks before the major nectar flow, and all the honey stored in the extracting combs should be removed from the honey supers at this time.

\title{
ACKNOWLEDGMENT
}

We thank Donald W. Clarke, Product Service Manager, Agricultural Division, Pfizer, Inc., for the assays for residues of OTC.

Received for publication in July 1980.

\begin{abstract}
RÉSUMÉ
LES RÉSIDUS D'OXYTETRACYCLINE DANS LE MIEL APRĖS ADMINISTRATION D'ANTIBIOTIQUE SELON TROIS MODES DIFFÉRENTS
\end{abstract}

L'efficacité des candis médicamenteux dans la lutte contre la loque européenne a été établie par LeHNERT et SHIMANuk1, 1980. Dans ce test l'oxytétracylcine (OTC) a été fournie aux colonies dans trois excipients différents et l'analyse des résidus faite sur le miel récolté. Celle-ci a été effectuée par la firme Chas. Pfizer. Les colonies ont démarré avec $1,36 \mathrm{~kg}$ d'abeilles et une reine de deux mois avant le début du test. $\mathrm{Ni}$ les abeilles ni le matériel n'avaient subi auparavant de traitement antibiotique. Quinze colonies ont été utilisées pour le test, réparties en cinq lots de trois colonies. Le premier lot reçut $200 \mathrm{~g}$ de candi médicamenteux contenant $200 \mathrm{mg}$ d'OTC; le deuxième lot du candi médicamenteux contenant $400 \mathrm{mg}$ d'OTC; les colonies du troisième lot furent saupoudrées de $28 \mathrm{~g}$ de sucre en poudre contenant $200 \mathrm{mg}$ d'OTC trois fois 
de suite à une semaine d'intervalle; celle du quatrième lot reçurent 2,51 de sirop de sucre à $50 \%$ contenant $200 \mathrm{mg}$ d'OTC; le cinquième lot constitua les témoins.

Un léger résidu d'OTC ne dépassant pas $0,5 \mathrm{ppm}$ fut trouvé dans le miel récolté sur l'une des trois colonies traitées avec le candi médicamenteux contenant $400 \mathrm{mg}$ d'OTC. Des résidus d'OTC ne dépassant pas 1,1 et 3,5 ppm ont été détectés dans le miel récolté sur deux des trois colonies qui avaient reçu l'antibiotique mélangé au sucre en poudre. Aucun résidu d'OTC n'a été retrouvé dans le miel sur les six colonies ayant reçu l'antibiotique dans le sirop de sucre ou le candi médicamenteux contenant $200 \mathrm{mg}$ d'OTC.

\title{
ZUSAMMENFASSUNG
}

\author{
OXYTETRACYCLIN-RUCKSTÄNDE IM HONIG \\ NACH DREI VERSCHIEDENEN DARBIETUNGSFORMEN DES ANTIBIOTIKUMS
}

Die Wirksamkeit von Wirkstoff-Futterteig zur Kontrolle der Europäischen Faulbrut wurde von LEHNERT und SHIMANUKI 1980 festgestellt. In diesem Test haben wir Oxytetracyclin (OTC) in drei verschiedenen Trägermitteln an Bienenvölker verfüttert und später liessen wir Rückstandsanalysen des geernteten Honigs machen. Die Rückstandsanalysen wurden von der Firma Chas. Pfizer durchgeführt.

Die Bienenvölker wurden zwei Monate vor Versuchsbeginn mit $1,36 \mathrm{~kg}$ Bienen und einer Königin gebildet. Weder die Bienen noch die Ausrüstung waren früher jemals mit dem Wirkstoff in Berührung gekommen. In dem Versuch wurden 15 Völker benutzt.

Drei Völker erhielten $200 \mathrm{~g}$ Wirkstoff-Futterteig mit einem Gehalt von $200 \mathrm{mg}$ OTC; drei Völker wurden mit Futterteig gefüttert, der $400 \mathrm{mg}$ OTC enthielt; drei Völker wurden dreimal mit $28 \mathrm{~g}$ Puderzucker mit einem Gehalt von $200 \mathrm{mg}$ OTC in Intervallen von je einer Woche gestäubt. Drei Völker wurden mit 2,5 Liter $50 \%$ Zuckersyrup gefüttert, der $200 \mathrm{mg}$ OTC enthielt; weitere drei Völker dienten als unbehandelte Kontrollen.

Bei einem von 3 Völkern, die mit $400 \mathrm{mg}$ OTC in Futterteig gefüttert worden waren, wurde im Honig eine kleine Menge - unter 0,5 ppm - von OTC-Rückständen gefunden. Im Schleuderhonig von 2 der 3 mit Antibiotikum-Puderzucker gestäubten Völkern wurden Rückstände zwischen 1,1 und 3,5 ppm festgestellt.

Dagegen wurden in den Schleuderhonigen von 6 Völkern, die $200 \mathrm{mg}$ OTC in Zuckerlösung oder in Futterteig erhalten hatten, keine Rückstände gefunden.

\section{REFERENCES}

Gilliam M. and ARGauer R. J., 1975. - Stability of oxytetracycline in diets fed to honeybee colonies for disease control. J. Invertebr. Pathol., 26 : 383-386.

LEHNERT T. and Shimanuki H., 1980. - European foulbrood control in honey bee colonies used for blueberry and cranberry pollination. Amer. Bee J., $120: 429-430$.

White J. W., Subers M. H. and SChepartz A. I., 1963. - The identification of inhibine, the antibacterial factor in honey, as hydrogen peroxide and its origin in a honey glucose-oxidase system. Biochem. Biophys. Acta, 73 : 57-70.

WILSON W. T., 1974. - Residues of oxytetracycline in honey stored by Apis mellifera. Environ. Entomol., $3:$ : 674-676.

Wilson W. T., Elliotr J. R. and HitchCock J. D., 1971. - Antibiotic extender patties for control of American foulbrood. J. Apic. Res., $10: 143-147$. 